\title{
Metabolic Studies in the African Pygmy
}

\author{
T. J. Mermmee, D. L. Rimoin, and L. L. Cavalli-Sforza \\ From the Department of Medicine, Boston University School of Medicine, \\ Boston, Massachusetts 02118; the Department of Medical Genetics, Harbor \\ General Hospital, Torrance, California 90509; and the Institute of Genetics, \\ University of Pavia, Milan, Italy
}

\begin{abstract}
A в S T R A C T Major metabolic effects of human growth hormone $(\mathrm{HGH})$ were assessed in the African Babinga pygmy. Plasma free fatty acid (FFA) and glucose concentrations were measured in pygmies, HGH-deficient dwarfs, Bantu tribesmen, and Caucasian controls after each received $4 \mathrm{mg}$ of $\mathrm{HGH}$ intravenously over a 20 min period. Pygmies had an early decrease of plasma FFA and glucose concentration, but did not exhibit a later lipolytic response.

In neighboring Bantu tribesmen, American controls, and $\mathrm{HGH}$-deficient dwarfs, both the early and late responses to intravenous $\mathrm{HGH}$ were present. The failure of plasma FFA concentration to increase in the pygmy after intravenous $\mathrm{HGH}$ was not due to a generalized defect in lipolysis since a normal lipolytic response was obtained with epinephrine $(2 \mu \mathrm{g} / \mathrm{min}$ for $20 \mathrm{~min}$ ).

Pygmies, like HGH-deficient dwarfs, had significantly reduced insulin responses to both oral glucose and arginine. Insulin secretion was significantly reduced when compared with either Bantu tribesmen or American controls and was not altered by 2 wk of a high carbohydrate/high protein diet. HGH treatment in pygmies (5 mg b.i.d. for 5 days) failed to augment either glucose or arginine-induced insulin secretion. Glucagon consistently caused normal insulin secretion in $\mathrm{HGH}-$ deficient dwarfs and was, likewise, effective in each pygmy studied. In two offspring from different pygmy mothers and Bantu fathers, insulin responses to glucose were initially normal and increased in a normal manner after $\mathrm{HGH}$ treatment.

In previous studies, $\mathrm{HGH}$ failed to reduce serum urea nitrogen concentration in pygmies. Sulfation factor was found to be normal. A consideration of the data in toto is consistent with a hypothesis that the metabolic findings in the pygmy may result from partial nonresponsiveness to either $\mathrm{HGH}$ or to a factor generated by
\end{abstract}

Received for publication 10 May 1971 and in rezised form 26 August 1971.
HGH. This defect is not transmitted as either an autosomal or sex-linked dominant trait.

\section{INTRODUCTION}

Pygmy subjects have normal increases of plasma immunoassayable $\mathrm{HGH}$ after appropriate stimuli and normal concentration of sulfation factor. Thus, a deficiency of human growth hormone $(\mathrm{HGH})^{1}$ can be excluded as a cause of their short stature (1). There were in our initial studies, however, clinical and biochemical findings. suggesting a similarity of pygmies and dwarfs with a monotropic deficiency of $\mathrm{HGH}$ (sexual ateliotic dwarfs) $(1,2)$. Both groups displayed $(a)$ abnormally prolonged hypoglycemia after exogenous insulin and $(b)$ insulinopenia after intravenous arginine and glucose.

Initial studies revealed, likewise, that plasma FFA concentrations did not increase in 19 pygmy subjects given $\mathrm{HGH}$ intravenously and that poor responsiveness was noted after 5 days of receiving $\mathrm{HGH}$ treatment. Effectiveness of $\mathrm{HGH}$ treatment was judged by comparing changes of insulin secretion and changes in serum urea nitrogen with those obtained in American controls and HGH-deficient dwarfs.

Although we interpreted our initial data to indicate end-organ unresponsiveness to $\mathrm{HGH}$ in the pygmy (2, 3 ), it was recognized that this hypothesis depended upon assumptions regarding the prior diet of these subjects and the suitability of the control population.

The present paper will focus upon four topics: (a) studies in pygmies both prepared and unprepared by special diets for $2 \mathrm{wk}$; $(b)$ comparative responses of Bantu, American controls, HGH-deficient dwarfs, and pygmy subjects with special reference to lipolytic hormones other than $\mathrm{HGH}$; (c) the possible site of the de-

${ }^{1}$ Abbreviation used in this paper: $\mathrm{HGH}$, human growth hormone. 
TABLE I

Plasma Glucose and Insulin Concentrations

\begin{tabular}{|c|c|c|c|c|c|c|}
\hline & \multirow[b]{2}{*}{ Time } & \multicolumn{5}{|c|}{ Glucose, $m g / 100 m l$ of plasma } \\
\hline & & $\mathbf{0}$ & 30 & 60 & $2 \mathrm{hr}$ & $3 \mathrm{hr}$ \\
\hline American controls (23) & & $82.9 \pm 4.1$ & $140.9 \pm 3.2$ & $139.3 \pm 5.8$ & $100.5 \pm 6.2$ & $90.3 \pm 5.6$ \\
\hline Bantu (8) & & $89.5 \pm 3.0$ & $129.0 \pm 9.3$ & $113.0 \pm 6.3$ & $86.1 \pm 9.0$ & $91.7 \pm 4.9$ \\
\hline HGH-deficient dwarfs (21) & & $79.4 \pm 7.1$ & $155.0 \pm 9.9^{*}$ & $195.6 \pm 18.8^{*}$ & $189.0 \pm 21.8^{*}$ & $137.3 \pm 2.4^{*}$ \\
\hline Pygmies (no diet) (19) & & $79.5 \pm 4.1$ & $123.8 \pm 8.3$ & $145.5 \pm 8.8$ & $95.6 \pm 3.9$ & \\
\hline Pygmies (diet) (7) & & $78.4 \pm 2.2$ & $113.2 \pm 5.5$ & $131.0 \pm 6.6$ & $109.5 \pm 9.4$ & $84.7 \pm 6.8$ \\
\hline
\end{tabular}

All values are means \pm SEM.

Plasma insulin responses of pygmies differ from Bantu and American controls at 30, 60, and $120 \mathrm{~min},(P<0.01)$. Glucose and insulin responses of pygmies fed a high carbohydrate/protein diet do not differ from pygmies unprepared by diet.

Insulin is given in microunits per milliliter.

* Indicates values are significantly $>$ than in pygmies, $P<0.01$ ).

fect in the pygmy; $(d)$ the inheritance of the "pygmy" trait.

\section{METHODS}

Studies in pygmies were conducted in three isolated villages in the Lobaye region of the Central African Republic-at Bagandou, Zomia, and Tobali. Pygmies studied at Bagandou were fed a diet composed of $400 \mathrm{~g}$ of carbohydrate and a minimum of $2 \mathrm{~g}$ of protein per $\mathrm{kg}$ of body weight daily divided into two meals. This diet was ingested completely for each of 14 days before any tests.

Sexual ateliotic dwarfs and normal controls were admitted to the Clinical Research Center for Boston University School of Medicine at Boston City Hospital. The diagnosis of sexual ateliosis (monotropic deficiency of $\mathrm{HGH}$ ) was established previously by multiple tests of pituitary function (1).

Growth hormone infusions. Five of the pygmies received growth hormone infusions consisting of $4 \mathrm{mg}$ of Wilhelmi $\mathrm{HGH}$ lot 1-C in $150 \mathrm{ml}$ of saline given in an antecubital vein over a $20 \mathrm{~min}$ period. Plasma samples were collected every $10 \mathrm{~min}$ for $60 \mathrm{~min}$ and then every $30 \mathrm{~min}$ for an additional $1 \frac{1}{2} \mathrm{hr}$. Five Bantu from a nearby village received similar infusions; four were conducted as in the pygmies. One Bantu subject received, inadvertently, $4 \mathrm{mg}$ of $\mathrm{HGH}$ in $8 \mathrm{~min}$ rather than the usual $20 \mathrm{~min}$ period. 10 normal American controls and $12 \mathrm{HGH}$-deficient dwarfs received similar infusions.

Glucose tolerance. Before controlling the diet and administering HGH, oral glucose tolerance tests were performed with $100 \mathrm{~g}$ of glucose. Subjects studied in this manner included 23 Caucasian controls, 8 Bantu, $21 \mathrm{HGH}-$ deficient dwarfs, and 19 pygmies. Plasma samples were collected every $30 \mathrm{~min}$. The American controls and $\mathrm{HGH}-$ deficient dwarfs had a carbohydrate intake of at least $150 \mathrm{~g}$ daily for 2 wk before testing. 11 of these pygmies, 6 of the Caucasian controls, and 6 of the sexual ateliotics had a second glucose tolerance test after receiving $5 \mathrm{mg}$ of $\mathrm{HGH}$ intramuscularly for 5 days. Five pygmies receiving the special diet were studied after the administration of glucose, but only one was treated with HGH. Two subjects, each known to be the offspring of different pygmy mothers and Bantu fathers had similar glucose tolerance tests. Each was then treated with $10 \mathrm{mg}$ of $\mathrm{HGH}$ intramuscularly daily for 2 days and the glucose tolerance tests were repeated.

Glucagon infusion studies. Five pygmies received $1 \mathrm{mg}$ of glucagon intravenously over a $20 \mathrm{~min}$ period. Six sexual ateliotics and seven normal controls were studied in a similar manner. To facilitate sampling at early time intervals, two intravenous infusions were used-one for infusion of glucagon, the second for sampling only. Samples were collected every $10 \mathrm{~min}$ for $60-90 \mathrm{~min}$.

Epinephrine infusion studies. Five pygmies not prepared by diet were given epinephrine infusions at a rate of 2 $\mu \mathrm{g} / \mathrm{min}$ for $60 \mathrm{~min}$. Plasma samples were collected at -15 , $0,20,40,60$, and 90 min. No Bantu subjects were studied with epinephrine, but five studies were conducted in sexual ateliotic dwarfs. 10 American controls had been studied previously in this manner.

On a previous expedition the effects of $\mathrm{HGH}$ upon sulfation factor, arginine-induced insulin secretion, and serum urea nitrogen concentration were studied. These data will be summarized in the text.

Collection of samples and methods of analysis. Using a portable centrifuge, serum was separated after each collection period, transferred to vials, and submerged slowly in a storage container of liquid nitrogen. Control vials containing $\mathrm{HGH}$ and insulin standards were treated in a similar manner to be certain rapid freezing did not destroy the hormones present in serum. Samples collected in all tests were analyzed for insulin, HGH, FFA, and glucose. Glucose and FFA were measured by methods described previously in detail $(3,6)$. Plasma growth hormone and insulin were measured by a dextran-coated charcoal modification of the initial immunoassay procedures of Yalow and Berson, and Glick, Roth, Yalow, and Berson $(4,5)$. The insulin assay was accurate to within $5 \mu \mathrm{U} / \mathrm{ml}$ and the growth hormone assay to within $0.5 \mathrm{ng} / \mathrm{ml}$ of plasma. For each hormone measurement, samples were analyzed in triplicate. If the discrepancy between samples was greater than $10 \%$ they were reanalyzed.

\section{RESULTS}

Glucose tolerance test. The mean glucose and insulin concentrations in plasma of all groups studied before $\mathrm{HGH}$ treatment are compared at pertinent time intervals 
after $100 \mathrm{~g}$ of Glucose Orally

\begin{tabular}{cccccc}
\hline & \multicolumn{4}{c}{ Insulin, $\mu U / m l$ of plasma } \\
\cline { 2 - 6 } Time & 0 & \multicolumn{5}{c}{30} & 60 & $2 \mathrm{hr}$ & $3 \mathrm{hr}$ \\
\hline $14.2 \pm 1.4$ & $76.9 \pm 11.3^{*}$ & $87.1 \pm 12.4^{*}$ & $64.6 \pm 5.5^{*}$ & $46.3 \pm 6.1^{*}$ \\
$27.8 \pm 5.4^{*}$ & $57.8 \pm 10.0^{*}$ & $70.0 \pm 4.3^{*}$ & $33.6 \pm 3.9$ & $28.0 \pm 4.6^{*}$ \\
$16.1 \pm 1.5$ & $27.4 \pm 4.0$ & $37.4 \pm 4.2$ & $43.3 \pm 5.8$ & $30.8 \pm 7.1^{*}$ \\
$15.4 \pm 2.1$ & $21.0 \pm 2.7$ & $25.3 \pm 3.9$ & $22.2 \pm 5.0$ & $12.8 \pm 2.2$ \\
$13.8 \pm 4.5$ & $17.2 \pm 3.5$ & $28.8 \pm 5.6$ & $23.0 \pm 6.3$ & 12.0 \\
\hline
\end{tabular}

after administration of glucose in Table I. The maximal glucose concentrations in plasma achieved after the ingestion of glucose were $140.9 \pm 3.2 \mathrm{mg} / 100 \mathrm{ml}^{2}$ in American controls, $129.0 \pm 9.3 \mathrm{mg} / 100 \mathrm{ml}$ in Bantu subjects, $195.6 \pm 18.8 \mathrm{mg} / 100 \mathrm{ml}$ in sexual ateliotics, and $131.0 \pm 6.6 \mathrm{mg} / 100 \mathrm{ml}$ in pygmies prepared with the high carbohydrate/high protein diet. This latter figure was similar to that noted in pygmies not prepared with the special diet, $(145.5 \pm 8.8 \mathrm{mg} / 100 \mathrm{ml}$ of plasma). Unlike the sexual ateliotic, the pygmy did not exhibit glucose intolerance.

The insulin responses of Bantu subjects and American controls were significantly greater than in pygmies. The mean peak insulin response to glucose in Bantu was $70.0 \pm 4.2 \mu \mathrm{U} / \mathrm{ml}$, in American controls, $87.1 \pm 12.4$ $\mu \mathrm{U} / \mathrm{ml}$, and in 11 pygmies not prepared by diet, 25.3 $\pm 3.9 \mu \mathrm{U} / \mathrm{ml}$. That these responses of the pygmy were not related to the prior diet or to the control group chosen is emphasized in Fig. 1. The mean maximal insulin response obtained in pygmies prepared by diet was $28.8 \pm 5.6 \mu \mathrm{U} / \mathrm{ml}$.

Fig. 2 compares the mean insulin responses with glucose before and after $\mathrm{HGH}$ treatment. Subjects studied are American controls, pygmies not prepared by diet, and HGH-deficient dwarfs. Similar responses of a single pygmy prepared by diet and two offspring of pygmy mothers and Bantu fathers are shown after a shorter course of $\mathrm{HGH}$ treatment in Fig. 3. The individual responses of 11 pygmies are also shown in Table II which indicates not only the initial level of response, but emphasizes the complete, uniform failure of the pygmy to respond to $\mathrm{HGH}$.

Both American controls and HGH-deficient dwarfs had a striking augmentation of their insulin responses

${ }^{2}$ All mean and mean maximal values are given with standard errors of the mean.

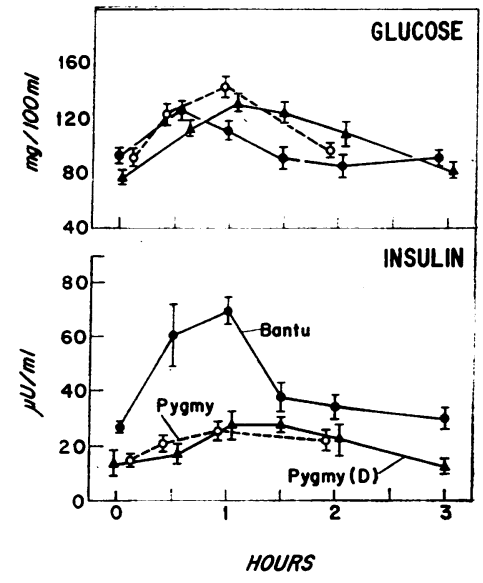

FIgURE 1 Plasma glucose and insulin concentrations are shown for Bantu, pygmies unprepared by diet, and pygmies prepared by diet (D). $100 \mathrm{~g}$ of glucose was ingested at time 0 . All points are means \pm SEM. Peak insulin responses of both pygmy groups at 30 and $60 \mathrm{~min}$ are significantly different from Bantu.

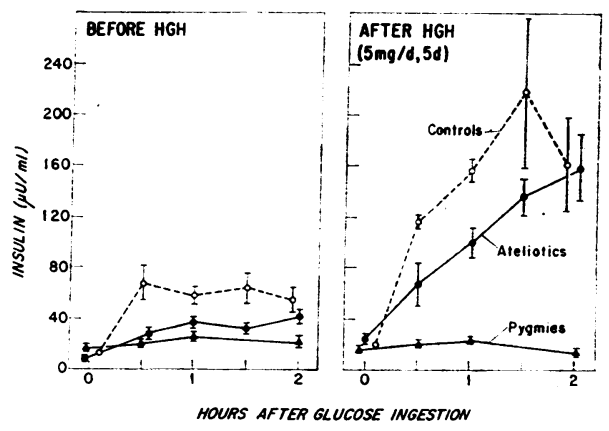

Figure 2 Plasma insulin concentrations after oral glucose $(100 \mathrm{~g})$ are shown before and after HGH treatment. All points are means \pm SEM.

Metabolic Studies in the African Pygmy 


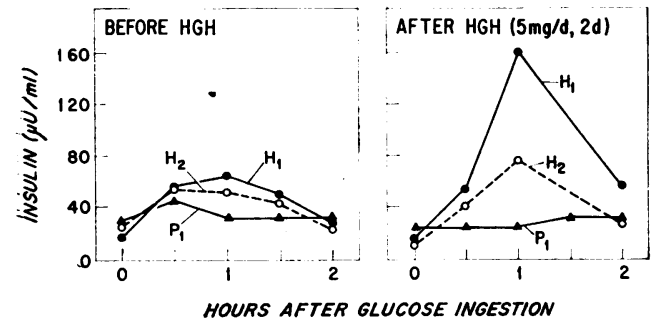

Figure 3 Plasma insulin concentrations after $100 \mathrm{~g}$ of glucose are shown before and after $\mathrm{HGH}$ treatment. $\mathrm{H}_{1}$ and $\mathrm{H}_{2}$ indicate offspring of pygmy mothers and Bantu fathers. $P_{1}$ is a pygmy prepared with a high protein-carbohydrate diet.

to glucose after receiving $\mathrm{HGH}$ for 5 days. The pygmy prepared by diet failed to increase his insulin response after receiving $\mathrm{HGH}$ for only 2 days, but two offspring of pygmy mothers and Bantu fathers (the only two studied) responded to this latter treatment with augmented insulin responses to glucose. The failure of the pygmy's insulin response to increase after $\mathrm{HGH}$ was noted previously after the infusion of arginine also. The mean data for this test are summarized in Table III.
Glucagon infusion. Unlike other stimuli for insulin secretion, the infusion of glucagon caused a similar increase of plasma insulin in both sexual ateliotics and pygmies-an increase which was similar with that seen in normal controls. The mean maximal response was $120.4 \pm 12.8 \mu \mathrm{U} / \mathrm{ml}$ in pygmies, $102.8 \pm 9.4 \mu \mathrm{U} / \mathrm{ml}$ in sexual ateliotics, and $101.6 \pm 19.3 \mu \mathrm{U} / \mathrm{ml}$ in normal Caucasian controls.

Intravenous growth hormone and epinephrine. Mean basal concentrations of FFA were similar in each group studied. After the rapid infusion of $4 \mathrm{mg}$ of $\mathrm{HGH}$, plasma FFA concentrations and plasma glucose concentrations decreased. The time course of these early changes with the subsequent increase of FFA concentration in all groups except the pygmy are emphasized in Fig. 4. Since the timing of each FFA response was obviously variable from one individual to the next, mean minimal and maximal plasma concentrations and the percentage change from basal are given in detail in Table IV. There was not a statistically significant difference between any groups in the early decrease of FFA or glucose, but pygmies had a significantly smaller increase of FFA than any other group studied; (pyg-

TABLE II

Effect of HGH upon Insulin Response to Glucose

\begin{tabular}{|c|c|c|c|c|c|c|c|c|}
\hline & \multicolumn{8}{|c|}{ Plasma insulin levels } \\
\hline & \multicolumn{4}{|c|}{ Before treatment } & \multicolumn{4}{|c|}{ After treatment } \\
\hline & 0 & 30 & 60 & $2 \mathrm{hr}$ & 0 & 30 & 60 & $2 \mathrm{hr}$ \\
\hline \multicolumn{9}{|l|}{ Pygmies } \\
\hline Subject 1 & 20.0 & 14.0 & 14.0 & 14.0 & 15.0 & 14.0 & 36.0 & 15.0 \\
\hline Subject 2 & 16.0 & 26.0 & 46.0 & 34.0 & 14.0 & 36.0 & 38.0 & - \\
\hline Subject 3 & 11.0 & 11.0 & 15.0 & 10.0 & 12.0 & 14.0 & 14.0 & 12.0 \\
\hline Subject 4 & 24.0 & 33.0 & - & 12.0 & 13.0 & 22.0 & 16.0 & 9.0 \\
\hline Subject 5 & 18.0 & 18.0 & 24.0 & 24.0 & 14.0 & 24.0 & 16.0 & 12.0 \\
\hline Subject 6 & 30.0 & 38.0 & - & - & 13.0 & 28.0 & 32.0 & 22.0 \\
\hline Subject 7 & 8.0 & 26.0 & 24.0 & 20.0 & 13.0 & 13.0 & 22.0 & 18.0 \\
\hline Subject 8 & 9.0 & 14.0 & 12.0 & 14.0 & 12.0 & 22.0 & 26.0 & 14.0 \\
\hline Subject 9 & 10.0 & 22.0 & 39.0 & 20.0 & 16.0 & 34.0 & 30.0 & 18.0 \\
\hline Subject 10 & 10.0 & 11.0 & 22.0 & 12.0 & 14.0 & 14.0 & 14.0 & 18.0 \\
\hline Subject 11 & 13.0 & 18.0 & 32.0 & 62.0 & 10.0 & 28.0 & 34.0 & 12.0 \\
\hline Mean & 15.3 & 21.0 & 25.3 & 22.2 & 13.3 & 22.6 & 24.7 & 15.0 \\
\hline SEM & 2.2 & 2.7 & 3.9 & 4.9 & 0.48 & 2.5 & 2.7 & 1.3 \\
\hline \multicolumn{9}{|c|}{ Caucasian controls (8) } \\
\hline Mean & 11.3 & 68.5 & 57.0 & 51.5 & 19.5 & $119.0^{*}$ & $156.0^{*}$ & $160.0^{*}$ \\
\hline SEM & 2.9 & 14.4 & 7.4 & 7.9 & 2.5 & 4.9 & 9.8 & 42.3 \\
\hline \multicolumn{9}{|c|}{ Sexual ateliotics (6) } \\
\hline Mean & 12.3 & 27.4 & 37.4 & 43.3 & 18.5 & 69.8 & $103.8^{*}$ & $158.2^{*}$ \\
\hline SEM & 1.5 & 3.9 & 4.2 & 5.8 & 4.0 & 19.9 & 11.0 & 27.4 \\
\hline
\end{tabular}

Insulin is given in microunits per milliliter.

* Indicates value is significantly $>$ than pretreatment value. 
TABLE III

Effect of HGH upon Insulin Responses to Arginine*

\begin{tabular}{|c|c|c|c|c|c|c|c|c|c|c|}
\hline & \multicolumn{10}{|c|}{ Plasma insulin levels } \\
\hline & \multicolumn{5}{|c|}{ Before treatment } & \multicolumn{5}{|c|}{ After treatment } \\
\hline & $\mathbf{0}$ & 30 & 60 & 90 & 120 & 0 & 30 & 60 & 90 & 120 \\
\hline Pygmies & 12.2 & 26.8 & 22.0 & 13.6 & 15.2 & 12.8 & 18.3 & 15.3 & 13.0 & - \\
\hline (19) & \pm 1.9 & \pm 3.6 & \pm 3.9 & \pm 1.7 & \pm 2.2 & \pm 1.6 & \pm 1.2 & \pm 3.5 & \pm 1.7 & - \\
\hline Caucasian & 21.5 & 81.5 & 49.2 & 28.0 & 27.7 & 23.0 & $290.0 \ddagger$ & $101.0 \ddagger$ & 33.0 & - \\
\hline Controls (8) & \pm 4.5 & \pm 19.0 & \pm 0.5 & \pm 4.9 & \pm 7.6 & \pm 1.3 & \pm 65.0 & \pm 10.5 & \pm 1.7 & - \\
\hline
\end{tabular}

* Insulin is given in microunits per milliliter. All values are mean \pm SEM.

$0.25 \mathrm{~g}$ of arginine per pound of body weight was given from time 0 to 30 .

$\ddagger$ Indicates value is significantly $>$ than pretreatment value.

mies vs. Bantu $P<0.01$, vs. normal $P<0.05$, vs. HGHdeficient dwarfs $P<0.01$ ).

The mean maximal FFA response to epinephrine was similar in growth hormone-deficient dwarfs and Babinga pygmies. Epinephrine caused an increase in plasma FFA concentration in each of these groups. The mean maximal increase of FFA over basal concentration was 150 $\pm 20.5 \%$ in pygmies and $158 \pm 16.0 \%$ in $\mathrm{HGH}$-deficient dwarfs. In a previous study, similar responses were noted in normal controls.

\section{DISCUSSION}

We have described previously two groups of dwarfs who have a monotropic deficiency of $\mathrm{HGH}$, and Laron has described a type of dwarfism in which high basal values of immunoreactive $\mathrm{HGH}$ are found (7-9). The present study was undertaken to clarify the problems which arose in our earlier attempts to delineate the endocrine status of the African pygmy.

On previous expeditions to the Central African Republic, we established that Babinga pygmies do not have a deficiency of $\mathrm{HGH}$, that their basal plasma $\mathrm{HGH}$ values are not elevated, and that several responses expected after $\mathrm{HGH}$ treatment were absent (1-3).

There were several problems which made it difficult to interpret the initial data. Although we had emphasized the poor insulin response of the pygmy to glucose after treatment with $\mathrm{HGH}$, it seemed possible that this could be secondary to dietary peculiarities and not simply the result of resistance to HGH. Furthermore, we had compared the pygmy in all studies with American controls, but if neighboring Bantu resembled the pygmy, the comparisons would be invalid. We, likewise, emphasized the lack of a lipolytic response (i.e. a late rise in FFA level above basal) after intravenous $\mathrm{HGH}$. This, however, could be nonspecific or, alternatively, might reflect a relatively greater physiologic effect of insulin in the pygmy. In addition to these problems, we had no information which aided in determining the site of the defect and its manner of inheritance.

That the impoverished insulin response of the pygmy noted initially was not related to diet is evident from the data given in Table I and Fig. 1. Despite the fact that pygmies were prepared with a special diet for $2 \mathrm{wk}$, their plasma insulin responses to a glucose load remained attenuated and were almost identical with responses obtained in pygmies not treated with a high carbohydrate/protein diet. Insulin responses of Bantu to glucose were very similar to those of American controls. Glucagon, the only simulus giving consistently a normal insulin response in $\mathrm{HGH}$-deficient dwarfs, also gave a similar response in pygmies. This would seem to further support the fact that decreased insulin responses of the

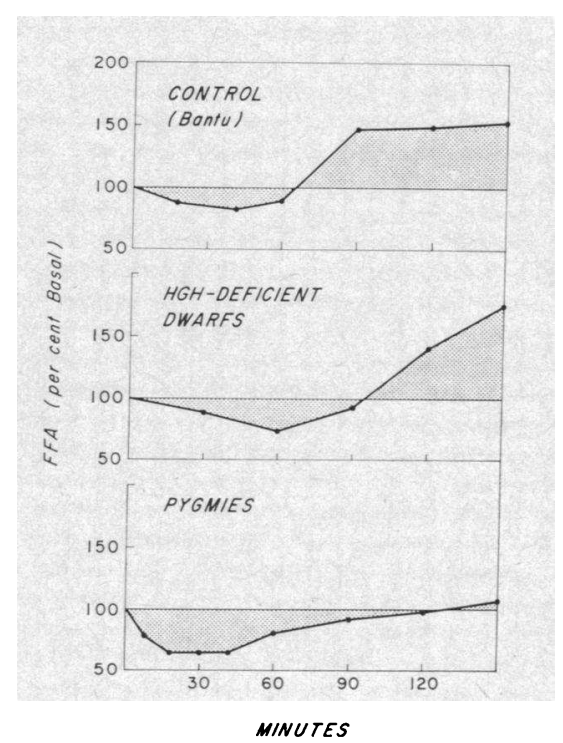

Figure 4 Free fatty acid concentration in plasma expressed as per cent of the basal FFA concentration is shown after $4 \mathrm{mg}$ of intravenous $\mathrm{HGH}$ given over $20 \mathrm{~min}$. 
TABLE IV

Effect of HGH Infusion on Plasma Glucose and FFA Concentrations*

\begin{tabular}{|c|c|c|c|c|c|c|c|}
\hline & \multirow{2}{*}{$\frac{\begin{array}{c}\text { Mean basal FFA } \\
\text { concentration }\end{array}}{\mu_{M} / m l}$} & \multicolumn{2}{|c|}{$\begin{array}{l}\text { Mean minimal FFA } \\
\text { concentration }\end{array}$} & \multicolumn{2}{|c|}{$\begin{array}{c}\text { Mean maximal FFA } \\
\text { concentration }\end{array}$} & \multicolumn{2}{|c|}{$\begin{array}{c}\text { Maximal decrease o } \\
\text { plasma }\end{array}$} \\
\hline & & $\mu E q / m l$ & $\begin{array}{l}\% \text { of } \\
\text { basal } \\
\text { level }\end{array}$ & $\mu E q / m l$ & $\begin{array}{l}\text { \% of } \\
\text { basal } \\
\text { level }\end{array}$ & $\begin{array}{r}m g / \\
100 m l\end{array}$ & $\begin{array}{l}\text { \% de- } \\
\text { crease } \\
\text { from } \\
\text { basal } \\
\text { level }\end{array}$ \\
\hline Pygmies (prepared by diet) & $0.653 \pm 0.092$ & $\begin{array}{c}0.384 \\
(59.0\end{array}$ & $\begin{array}{l} \pm 0.099^{*} \\
\pm 9.4 \%)\end{array}$ & $\begin{array}{r}708.0 \\
(107.0\end{array}$ & $\begin{array}{l} \pm 0.074 \\
\pm 8.8 \%)\end{array}$ & $\begin{array}{r}15.4 \\
(17.5\end{array}$ & $\begin{array}{l} \pm 2.1^{*} \\
\pm 1.9 \%)\end{array}$ \\
\hline Bantu & $0.652 \pm 0.084$ & $\begin{array}{c}0.394 \\
(60.2\end{array}$ & $\begin{array}{l} \pm 0.090^{*} \\
\pm 10.3 \% \text { ) }\end{array}$ & $\begin{array}{l}1.078 \\
(165.0\end{array}$ & $\begin{array}{l} \pm 1.00^{*} \\
\pm 21.0 \%)\end{array}$ & $\begin{array}{r}20.5 \\
(18.8\end{array}$ & $\begin{array}{l} \pm 6.6^{*} \\
\pm 4.6 \%)\end{array}$ \\
\hline HGH-deficient dwarfs & $0.800 \pm 0.102$ & $\begin{array}{l}0.442 \\
(55.0\end{array}$ & $\begin{array}{l} \pm 0.083^{*} \\
\pm 12.0 \%)\end{array}$ & $\begin{aligned} & 1.402 \\
&(175.0\end{aligned}$ & $\begin{array}{l} \pm 0.126^{*} \\
+16.3 \%)\end{array}$ & $\begin{array}{r}16.9 \\
(17.0\end{array}$ & $\begin{array}{l} \pm 4.3^{*} \\
\pm 2.3 \%)\end{array}$ \\
\hline American controls & $0.608 \pm 0.062$ & $\begin{array}{l}0.394 \\
(65.0\end{array}$ & $\begin{array}{l} \pm 0.070^{*} \\
\pm 9.3 \%)\end{array}$ & $\begin{array}{l}0.923 \\
(151.0\end{array}$ & $\begin{array}{l} \pm 0.064^{*} \\
\pm 7.8 \%)\end{array}$ & & - \\
\hline
\end{tabular}

The initial decreases of FFA and glucose concentrations occurred within 40 min. All increases of plasma FFA concentrations occurred between 60 and $150 \mathrm{~min}$.

* Indicates value differs significantly both from basal state and from maximum variation obtained in 12 control studies with the infusion of saline.

pygmy to glucose and arginine' were somehow related to HGH. This finding, however, need not be overemphasized. Indeed, the insulin output of the pygmy to glucose may well be functionally appropriate. The point of major importance is not the appropriateness or inappropriateness of the pygmies initial insulin response to glucose, but the consistent failure of insulin secretion to increase after exogenous $\mathrm{HGH}$ was administered. In our experience, it remains striking and unique to find any group in which every individual studied failed to augment insulin secretion after $\mathrm{HGH}$ therapy.

The FFA responses after acute administration of $\mathrm{HGH}$ also support the view that $\mathrm{HGH}$ is at least partially ineffective in these individuals. As indicated in Fig. 4, the infusion of $\mathrm{HGH}$ failed to increase FFA levels in pygmies. Increases were readily detectable in control subjects, (including the Bantu) and in sexual ateliotics. As with insulin secretion, diet does not explain these results and our "control" studies appear suitable since Bantu from the same area do not show patterns similar to the pygmy. As with insulin output after $\mathrm{HGH}$ therapy, it remains possible that the impaired rise in FFA levels is related somehow to a greater physiologic activity of insulin in the pygmy. If so, it is an uniquely specific effect, since insulin did not alter the increase of FFA levels obtained with epinephrine.

The exact nature of the metabolic defect in the pygmy cannot be described with complete assurance, but the data seem to us most consistent with two possibilities: (a) An intracellular defect in $\mathrm{HGH}$-mediated protein synthesis or (b) a similar, partial insensitivity to a
HGH-dependent substance such as sulfation factor. Although early responses to $\mathrm{HGH}$ (as we tested them) might well be pharmacologic effects, they are known to be independent of DNA-medicated protein synthesis. $(10,11)$. The crucial metabolic reactions responsible for a normal growth rate, such as the over-all protein synthetic rate, are probably abnormal in the pygmy as indicated by the failure of $\mathrm{HGH}$ to increase lipolysis, augment insulin secretion, or reduce serum urea nitrogen concentration. These reactions are blocked readily by agents interfering with DNA-mediated protein synthesis (10-12). For example, the need for $\mathrm{HGH}$ to induce intracellular protein synthesis for its lipolytic action is fairly well documented $(13,14)$. Similarly, the ability of $\mathrm{HGH}$ to alter insulin secretion is clearly an effect requiring a minimum of hours and usually several days (15). There are normal basal levels of plasma $\mathrm{HGH}$ in the pygmy. If the above speculation is correct, this might indicate that neural centers controlling $\mathrm{HGH}$ secretion are not dependent upon a HGH-mediated protein synthetic process.

It cannot be determined at present whether the insensitivity noted is to $\mathrm{HGH}$, per se, or to a substance generated by $\mathrm{HGH}$. It is known that sulfation factor is normal in the pygmy, so one must consider the possibility that anabolic effects attributed to $\mathrm{HGH}$ are induced by an intermediary. It is not possible to speculate whether there is an unknown antagonist to the action of $\mathrm{HGH}$ or whether the HGH of the pygmy is anomalous, retaining immunoreactivity but lacking biological activity. With the present data, the latter possibility is highly unlikely. One would expect decreased responsiveness to 
exogenous $\mathrm{HGH}$ only if the concentration of the anomalous hormone were increased.

Too few subjects were studied to state conclusively the manner in which the "pygmy" trait was inherited. Despite a considerable effort to locate such subjects, only two could be identified positively as the offspring of pygmy/Bantu parents. That the defect is not inherited as a dominant trait is apparent from studies conducted in these two hybrids. Fig. 2 shows the plasma insulin response to oral glucose before and after HGH treatment in controls, sexual ateliotics, and pygmies. Each of these subjects had received $5 \mathrm{mg}$ of $\mathrm{HGH}$ daily for 5 days. Although the two hybrids were treated with $\mathrm{HGH}$ for 2 days only, each showed an increase of their plasma insulin response to glucose.

In summary, the pygmy has several defective responses to HGH. These probably involve actions of HGH dependent upon late protein synthetic processes. Offspring of pygmy mothers and Bantu fathers do not show abnormal insulin responses to glucose and readily augment their insulin responses to $\mathrm{HGH}$ treatment, indicating that the defect is not inherited as a dominant trait. Although isolated cases of insensitivity to a peptide hormone have been described, the defect in the pygmy appears unique in that it effects an entire race.

\section{ACKNOWLEDGMENTS}

We wish to acknowledge the critical analysis of these data by Dr. John Eager Howard and Dr. Victor McKusick.

This work was supported in part by U. S. Public Health Service Grants, 5-R01-GM10189, HD-02422, AM-13565, and RR-533 (General Clinical Research Program of the Division of Research Resources). The expedition was organized by L. L. Cavalli-Sforza and supported by grants from the Italian I.B.P. Committee of the Consiglio Nazionale delle Richerche and by the World Health Organization.

\section{REFERENCES}

1. Rimoin, D. L., T. J. Merimee, D. Rabinowitz, and V. A. McKusick. 1968. Genetic aspects of clinical endocrinology. Recent Progr. Hormone Res. 24: 365.
2. Merimee, T. J., D. L. Rimoin, D. Rabinowitz, L. L. Cavalli-Sforza, and V. A. McKusick. 1968. Metabolic effects of HGH in the African Pygmy. Lancet. 1: 194.

3. Merimee, T. J., D. L. Rimoin, D. Rabinowitz, L. L. Cavalli-Sforza, and V. A. McKusick. 1968. Metabolic studies in the African Pygmy. Trans. Ass. Amer. Physicians Philadelphia. 81: 221.

4. Yalow, R. S., and S. A. Berson. 1960. Immunoassay of endogenous plasma insulin in man. J. Clin. Invest. 39: 1159.

5. Glick, S. M., J. Roth, R. S. Yalow, and S. A. Berson. 1963. Immunoassay of growth hormone in plasma. Nature (London). 119: 784.

6. Dole, V. P. 1956. A relation between non-esterified fatty acids in plasma and the metabolism of glucose. J. Clin. Invest. $35: 150$.

7. Merimee, T. J., J. A. Burgess, and D. Rabinowitz. 1967. Influence of growth hormone on insulin secretion. Diabetes. $16: 478$.

8. Merimee, T. J., D. L. Rimoin, J. G. Hall, and V. A. McKusick. 1969. A metabolic and hormonal basis for classifying sexual ateliotic dwarfs. Lancet. 1: 963.

9. Laron, A., A. Pentzelon, and S. Mannheimer. 1966. Genetic pituitary dwarfism with high serum concentration of growth hormone. Israel J. Med. Sci. 2: 152.

10. DeBodo, R. C., and N. Altszuler. 1957. The metabolic effects of growth hormone and their physiologic significance. Vitamins Hormones. 15: 206.

11. Swislucki, N. I., and C. M. Szego. 1965. Acute reduction of plasma nonesterified fatty acid by growth hormone in hypophysectomized and Houssay rats. Endocrinology. 76: 665 .

12. Goodman, H. M. 1968. Growth hormone and the metabolism of carbohydrate and lipid in adipose tissue. Ann. N. Y. Acad. Sci. 148: 419.

13. Fain, J. N., and R. Saperstein. 1970. The involvement of RNA synthesis and cyclic AMP in the activation of fat cell lipolysis by growth hormone and glucocorticoids. In Adipose Tissue Regulation and Metabolic Findings. B. Heanrenaud and D. Hepp, editors. Academic Press Inc., New York. 20.

14. Fain, J. N., A. Dodd, and L. Novak. 1971. Relationship of protein synthesis and cyclic AMP to lipolytic action of growth hormone and glucocorticoids. Metab. (Clin. Exp.). 20: 109.

15. Merimee, T. J., D. Rabinowitz, D. L. Rimoin, and V. A. McKusick. 1968. Sexual ateliotic dwarfism IV: the response of sexual ateliotic dwarfs to exogenous growth hormone. Metab. (Clin. Exp.). 16: 1012. 